\title{
Feasibility study of flood risk monitoring based on optical satellite data
}

\begin{abstract}
This article presents an extensive feasibility study of the use of optical satellite data for flood risk monitoring. The article presents a review of existing and archival satellite systems. The capabilities and restrictions of using earth observation data are presented, in relation to the identified threat and taking into account the size, genesis and cause. The initial results of the studies demonstrate the potential of very high and highresolution satellite imagery for the operational detection of damage and risk areas. In the presented approach, two analyses were conducted: bare soil detection and water range detection, based on different radiometric indices. As a result of the conducted research, the best results in bare soil detection were obtained using the MSAVI and NDVI indices. The most effective at delimiting water was the NDVI index. The automatization of satellite data processing from different satellite systems gives opportunities for hydrological services and crisis management professionals to access accurate and up-to-date information about the condition of levees for the early detection of flood risk.

Keywords

floods - satellites - optical imaging - monitoring • detection • risk management
\end{abstract}

(c) University of Warsaw - Faculty of Geography and Regional Studies

Introduction

Flood hazard monitoring covers a wide range of activities: from forecasting rainfalls to monitoring flood infrastructures. The research of flood risk monitoring based on the optical satellite data was conducted as part of the SAFEDAM project - "Advanced technologies in the prevention of flood hazard". The project is financed by the National Centre for Research and Development in Defence and Security Programme. The aim of the SAFEDAM project is to develop an innovative system enabling the risk of river floods in Poland to be monitored using, inter alia, unmanned aerial platform, satellite and aerial data. For this purpose, different photogrammetric and remote sensing techniques were tested and will be used in monitoring the flood risk, the flood phenomenon and the condition of levees. A comprehensive system will enable the multi-source collection of data, automatic data analysis and visualization for hydrological services and crisis management professionals.

\section{Satellite Earth Observation}

For the purpose of flood risk monitoring, depending on the scale on which the analysis is performed, a variety of satellite data is used. In order to carry out effective monitoring, several conditions must be met: 1 . data should be collected at the appropriate frequency depending on the mode (preventive/ operational); 2 . the data should be adequately detailed to provide information on the state of the water and the status of the flood embankments.

Data from meteorological systems is useful to forecast precipitation and its intensity. Very high-resolution satellite images (VHRS) and high-resolution satellite images (HRS) can
Beata Weintrit ${ }^{1,2}$, Katarzyna OsińskaSkotak $^{2}$, Magdalena Pilarska ${ }^{2}$

${ }^{1}$ Astri Polska Sp. z 0.o., Poland e-mail: beata.weintrit@astripolska.pl

${ }^{2}$ Department of Photogrammetry, Remote Sensing and Spatial Information Systems, Faculty of Geodesy and Cartography, Warsaw University of Technology, Poland, e-mail: k.osinska-skotak@pw.edu.pl e-mail: magdalena.pilarska@pw.edu.pl

Received: 21 January 2018 Accepted: 14 April 2018 be used to monitor flood embankments and their condition, and to monitor floodplains. This applies to both radar and optical data. Radar data is weather independent and generally considered to be better suited for water detection (Pluto-Kossakowska et al. 2017), while optical data is easier for photointerpretation and acts as a compaction of measurements from radar data.

The method of performing flood risk maps and flood risk monitoring has been presented by Skakun (2012) for Namibia with the use of multi-temporal LANDSAT images. Shaker et al. (2012) determined one of the best methods of using SPOT PAN satellite data to estimate the risk of flooding. Malinowski et al. (2015) conducted a study in which the total accuracy of twelve maps of flood ranges obtained by the decision tree method ranged between $77 \%$ and $95 \%$. Asare-Kyei et al. (2015) used RapidEye satellite data to produce land cover maps in order to obtain flood risk indicator maps. An analogous approach which presents the usage of optical and radar satellite data to produce flood risk maps (where optical data is used for the implementation of land cover maps) and, based on radar data, identified the extent of the flood presented, was introduced by Stancalie et al. (2007). Byun et al. (2015) present a methodology for detection of flood changes based on VHRS KOMPSAT images from two dates without the need for user interaction. Cundill's (2014) article presents the usage of remote sensing as a tool for the inspection of grass-covered embankments. Summarising the existing studies, various research teams use different methods and indices to identify flood risk areas depending on both the type of the area of interest and the data availability (the issue of costs and availability of data in the archive). Optical data is typically used to obtain information 
Table 1. VHRS optical satellite data parameters

\begin{tabular}{|c|c|c|c|c|c|c|c|c|c|}
\hline \multicolumn{2}{|c|}{ Satellite/ Sensor } & Ikonos & Eros A & QuickBird & OrbView-3 & Eros B & $\begin{array}{l}\text { KOMP- } \\
\text { SAT-2 }\end{array}$ & $\begin{array}{l}\text { CARTO- } \\
\text { SAT-2 }\end{array}$ & $\begin{array}{l}\text { World- } \\
\text { View-1 }\end{array}$ \\
\hline \multicolumn{2}{|c|}{$\begin{array}{l}\text { Nationality/ } \\
\text { Company }\end{array}$} & $\begin{array}{c}\text { GeoEye } \\
\text { (previously } \\
\text { Space } \\
\text { Imaging), } \\
\text { USA }\end{array}$ & $\begin{array}{c}\text { ImageSat } \\
\text { International, } \\
\text { Israel }\end{array}$ & $\begin{array}{c}\text { Digital } \\
\text { Globe, USA }\end{array}$ & $\begin{array}{l}\text { Orblmage, } \\
\text { USA }\end{array}$ & $\begin{array}{c}\text { ImageSat } \\
\text { International, } \\
\text { Israel }\end{array}$ & $\begin{array}{l}\text { KARI, } \\
\text { South } \\
\text { Korea }\end{array}$ & ISRO, India & $\begin{array}{c}\text { Digital } \\
\text { Globe, USA }\end{array}$ \\
\hline \multicolumn{2}{|c|}{ Operating time } & $\begin{array}{c}\text { since } \\
24.09 .1999\end{array}$ & $\begin{array}{c}\text { since } \\
05.12 .2000\end{array}$ & $\begin{array}{c}18.10 .2001 \\
- \\
17.12 .2014\end{array}$ & $\begin{array}{c}26.06 .2003 \\
-03.2007\end{array}$ & $\begin{array}{c}\text { since } \\
25.04 .2006\end{array}$ & $\begin{array}{c}\text { since } \\
28.07 .2006\end{array}$ & $\begin{array}{c}\text { since } \\
10.01 .2007\end{array}$ & $\begin{array}{c}\text { since } \\
18.09 .2007\end{array}$ \\
\hline \multicolumn{2}{|c|}{$\begin{array}{l}\text { Orbit altitude } \\
{[\mathrm{km}]}\end{array}$} & $681-709$ & $475-491$ & 450 & 470 & 500 & 685 & 630 & 496 \\
\hline \multirow{5}{*}{$\begin{array}{c}\text { Spectral } \\
\text { bands } \\
\text { [um] }\end{array}$} & PAN & $0.45-0.90$ & $0.50-0.90$ & $0.45-0.90$ & $0.45-0.90$ & $0.50-0.90$ & $0.50-0.90$ & $0.50-0.85$ & $0.45-0.80$ \\
\hline & MS & $0.45-0.52$ & & $0.45-0.52$ & $0.45-0.52$ & & $0.45-0.52$ & & \\
\hline & & $0.52-0.61$ & & $0.52-0.60$ & $0.52-0.60$ & & $0.52-0.60$ & & \\
\hline & & $0.64-0.72$ & & $0.63-0.69$ & $0.62-0.69$ & & $0.63-0.69$ & & \\
\hline & & $0.72-0.88$ & & $0.76-0.90$ & $0.76-0.90$ & & $0.76-0.90$ & & \\
\hline \multirow{2}{*}{$\begin{array}{c}\text { Spatial } \\
\text { resolution } \\
{[\mathrm{m}]}\end{array}$} & PAN & $0.82 \times 0.82$ & $\begin{array}{l}1.0 \times 1.0- \\
1.8 \times 1.8\end{array}$ & $0.61 \times 0.61$ & $1 \times 1$ & $0.7 \times 0.7$ & $1 \times 1$ & $0.8 \times 0.8$ & $0.50 \times 0.50$ \\
\hline & MS & $3.28 \times 3.28$ & & $2.44 \times 2.44$ & $4 \times 4$ & $1.9 \times 1.9$ & $4 \times 4$ & & \\
\hline \multicolumn{2}{|c|}{$\begin{array}{c}\text { Radiometric } \\
\text { resolution [bit] }\end{array}$} & 11 & 11 & 11 & 11 & 11 & 10 & 11 & 11 \\
\hline \multicolumn{2}{|c|}{ Footprint [km] } & $11 \times 11$ & $13.5 \times 13.5$ & $16 \times 16$ & $8 \times 8$ & $14 \times 14$ & $15 \times 15$ & $9.6 \times 9.6$ & $17.6 \times 17.6$ \\
\hline \multicolumn{2}{|c|}{$\begin{array}{c}\text { Maximum angle } \\
\text { of incidence }\end{array}$} & $+/-45^{\circ}$ & $+/-43^{\circ}$ & $+/-30^{\circ}$ & $+/-45^{\circ}$ & $+/-45^{\circ}$ & $+/-60^{\circ}$ & $+/-45^{\circ}$ & $+/-45^{\circ}$ \\
\hline \multicolumn{2}{|c|}{ Satellite/ Sensor } & Geoeye-1 & WorldView-2 & $\begin{array}{c}\text { CartoSat- } \\
\text { 2B } \\
\end{array}$ & Plèiades-1A & KOMPSAT-3 & $\begin{array}{c}\text { Plèiades- } \\
\text { 1B }\end{array}$ & $\begin{array}{l}\text { World- } \\
\text { View-3 }\end{array}$ & $\begin{array}{l}\text { KOMP- } \\
\text { SAT-3A }\end{array}$ \\
\hline \multicolumn{2}{|c|}{$\begin{array}{l}\text { Nationalityl } \\
\text { Company }\end{array}$} & $\begin{array}{c}\text { GeoEye } \\
\text { (previously } \\
\text { Space } \\
\text { Imaging), } \\
\text { USA } \\
\end{array}$ & $\begin{array}{c}\text { Digital Globe, } \\
\text { USA }\end{array}$ & ISRO, India & $\begin{array}{c}\text { CNES, } \\
\text { AIRBUS } \\
\text { Defence } \\
\text { \& Space, } \\
\text { France }\end{array}$ & $\begin{array}{l}\text { KARI, South } \\
\text { Korea }\end{array}$ & $\begin{array}{c}\text { CNES, } \\
\text { AIRBUS } \\
\text { Defence } \\
\text { \& Space, } \\
\text { France }\end{array}$ & $\begin{array}{l}\text { Digital } \\
\text { Globe, } \\
\text { USA }\end{array}$ & $\begin{array}{l}\text { KARI, } \\
\text { South } \\
\text { Korea }\end{array}$ \\
\hline \multicolumn{2}{|c|}{ Operating time } & $\begin{array}{c}\text { since } \\
06.09 .2008\end{array}$ & $\begin{array}{c}\text { since } \\
08.10 .2009\end{array}$ & $\begin{array}{c}\text { since } \\
12.07 .2010\end{array}$ & $\begin{array}{c}\text { since } \\
17.12 .2011\end{array}$ & $\begin{array}{c}\text { since } \\
17.05 .2012\end{array}$ & $\begin{array}{c}\text { since } \\
02.12 .2012\end{array}$ & $\begin{array}{c}\text { since } \\
13.08 .2014\end{array}$ & $\begin{array}{c}\text { since } \\
25.03 .2015\end{array}$ \\
\hline \multicolumn{2}{|c|}{$\begin{array}{c}\text { Orbit altitude } \\
{[\mathrm{km}]}\end{array}$} & 681 & 770 & 637 & 694 & 685 & 694 & 617 & 528 \\
\hline \multirow{9}{*}{$\begin{array}{c}\text { Spectral } \\
\text { bands } \\
\text { [um] }\end{array}$} & PAN & $0.45-0.90$ & $0.45-0.80$ & $0.45-0.85$ & $0.48-0.83$ & $0.45-0.90$ & $0.48-0.83$ & $0.45-0.80$ & $0.45-0.90$ \\
\hline & MS & $0.45-0.52$ & $0.40-0.45$ & & $0.43-0.55$ & $0.45-0.52$ & $0.43-0.55$ & $0.40-0.45$ & $0.45-0.52$ \\
\hline & & $0.52-0.60$ & $0.45-0.52$ & & $0.49-0.61$ & $0.52-0.60$ & $0.49-0.61$ & $0.45-0.51$ & $0.52-0.60$ \\
\hline & & $0.63-0.70$ & $0.51-0.58$ & & $0.60-0.72$ & $0.63-0.69$ & $0.60-0.72$ & $0.51-0.58$ & $0.63-0.69$ \\
\hline & & $0.76-0.90$ & $0.59-0.63$ & & $0.75-0.95$ & $0.76-0.90$ & $0.75-0.95$ & $0.59-0.63$ & $0.76-0.90$ \\
\hline & & & $0.63-0.69$ & & & & & $0.63-0.69$ & \\
\hline & & & $0.71-0.75$ & & & & & $0.71-0.75$ & \\
\hline & & & $0.77-0.90$ & & & & & $0.77-0.90$ & \\
\hline & & & $0.86-1.04$ & & & & & $0.86-1.04$ & \\
\hline \multirow{2}{*}{$\begin{array}{c}\text { Spatial } \\
\text { resolution } \\
{[\mathrm{m}]}\end{array}$} & PAN & $0.41 \times 0.41$ & $0.46 \times 0.46^{1}$ & $0.8 \times 0.8$ & $0.5 \times 0.5$ & $0.7 \times 0.7$ & $0.5 \times 0.5$ & $0.31 \times 0.31^{1}$ & $0.5 \times 0.5$ \\
\hline & MS & $1.65 \times 1.65$ & $1.84 \times 1.84$ & & $2 \times 2$ & $2.8 \times 2.8$ & $2 \times 2$ & $1.24 \times 1.24$ & $2 \times 2$ \\
\hline \multicolumn{2}{|c|}{$\begin{array}{c}\text { Radiometric } \\
\text { resolution [bit] }\end{array}$} & 11 & 11 & 10 & 12 & 14 & 12 & 11 & 14 \\
\hline \multicolumn{2}{|c|}{ Footprint [km] } & $15 \times 15$ & $16.4 \times 16.4$ & $9.6 \times 9.6$ & $20 \times 20$ & $15 \times 15$ & $20 \times 20$ & $13.1 \times 13.1$ & $12 \times 12$ \\
\hline \multicolumn{2}{|c|}{$\begin{array}{l}\text { Maximum angle } \\
\text { of incidence }\end{array}$} & $+/-60^{\circ}$ & $+/-45^{\circ}$ & $+/-45^{\circ}$ & $+/-45^{\circ}$ & $+/-45^{\circ}$ & $+/-45^{\circ}$ & $+/-45^{\circ}$ & $+/-45^{\circ}$ \\
\hline
\end{tabular}

Source: own elaboration based on: Airbus Defence and Space 2018, Satellite Imaging Corporation 2018, DigitalGlobe 2018, ESA Earth Online 2018. 
MISCELLANEA GEOGRAPHICA - REGIONAL STUDIES ON DEVELOPMENT

Vol. $22 \cdot$ No. $3 \cdot 2018 \cdot$ pp. 172-180 •ISSN: 2084-6118 • DOI: 10.2478/mgrsd-2018-0011

Table 2. Selected high resolution (HRS) optical satellite data parameters

\begin{tabular}{|c|c|c|c|c|c|c|c|c|}
\hline \multicolumn{2}{|c|}{$\begin{array}{l}\text { Satellite/ } \\
\text { Sensor }\end{array}$} & $\begin{array}{l}\text { LANDSAT-7I } \\
\text { ETM+ }\end{array}$ & SPOT5 & $\begin{array}{c}\text { ALOS/ } \\
\text { PRISM/ } \\
\text { AVNIR-2 }\end{array}$ & SPOT6/7 & LDCM/OLI & Sentinel-2A & Sentinel-2B \\
\hline \multicolumn{2}{|c|}{$\begin{array}{c}\text { Nationality/ } \\
\text { Company }\end{array}$} & NASA, USA & $\begin{array}{l}\text { AIRBUS Defence \& } \\
\text { Space (previously } \\
\text { Spotlmage), France }\end{array}$ & JAXA, Japan & $\begin{array}{l}\text { AIRBUS } \\
\text { Defence } \\
\text { \& Space, } \\
\text { France }\end{array}$ & NASA, USA & $\begin{array}{l}\text { ESA, } \\
\text { European } \\
\text { Union }\end{array}$ & $\begin{array}{l}\text { ESA, } \\
\text { European } \\
\text { Union }\end{array}$ \\
\hline \multicolumn{2}{|c|}{ Operating time } & $\begin{array}{c}\text { since } \\
15.04 .1999 \\
\end{array}$ & $\begin{array}{c}04.05 .2002- \\
31.03 .2015 \\
\end{array}$ & $\begin{array}{c}\text { since } \\
24.01 .2006 \\
\end{array}$ & $\begin{array}{c}\text { since } \\
12.09 .2012 \\
\end{array}$ & $\begin{array}{c}\text { since } \\
11.02 .2013 \\
\end{array}$ & $\begin{array}{c}\text { since } \\
23.06 .2015 \\
\end{array}$ & $\begin{array}{c}\text { since } \\
07.03 .2017\end{array}$ \\
\hline \multicolumn{2}{|c|}{$\begin{array}{c}\text { Orbit altitude } \\
{[\mathrm{km}]}\end{array}$} & 705 & 832 & 692 & 832 & 705 & 786 & 786 \\
\hline \multirow{13}{*}{$\begin{array}{l}\text { Spectral } \\
\text { bands } \\
\text { [um] }\end{array}$} & PAN & $0.52-0.90$ & $0.48-0.71$ & $0.52-0.77$ & $0.455-0.745$ & $0.500-0.680$ & $0.430-0.457$ & $0.420-0.465$ \\
\hline & MS & $0.45-0.52$ & $0.50-0.59$ & $0.42-0.50$ & $0.455-0.525$ & $0.433-0.453$ & $0.448-0.546$ & $0.443-0.541$ \\
\hline & & $0.52-0.60$ & $0.61-0.68$ & $0.52-0.60$ & $0.530-0.590$ & $0.450-0.515$ & $0.538-0.583$ & $0.536-0.582$ \\
\hline & & $0.63-0.69$ & $0.78-0.89$ & $0.61-0.69$ & $0.625-0.695$ & $0.525-0.600$ & $0.646-0.684$ & $0.646-0.685$ \\
\hline & & $0.76-0.90$ & $1.58-1.75$ & $0.76-0.89$ & $0.760-0.890$ & $0.630-0.680$ & $0.694-0.713$ & $0.694-0.714$ \\
\hline & & $1.55-1.75$ & & & & $0.845-0.885$ & $0.731-0.749$ & $0.730-0.748$ \\
\hline & & $10.40-12.50$ & & & & $1.560-1.660$ & $0.769-0.797$ & $0.766-0.794$ \\
\hline & & $2.08-2.35$ & & & & $2.100-2.300$ & $0.763-0.908$ & $0.767-0.900$ \\
\hline & & & & & & $1.360-1.390$ & $0.848-0.881$ & $0.848-0.880$ \\
\hline & & & & & & & $0.932-0.958$ & $0.930-0.957$ \\
\hline & & & & & & & $1.336-1.411$ & $1.339-1.415$ \\
\hline & & & & & & & $1.542-1.685$ & $1.540-1.681$ \\
\hline & & & & & & & 2.081-2.323 & $2.067-2.305$ \\
\hline \multirow{2}{*}{$\begin{array}{l}\text { Spatial } \\
\text { resolution } \\
{[\mathrm{m}]}\end{array}$} & PAN & $15 \times 15$ & $2.5 \times 2.5,5.0 \times 5.0$ & $2.5 \times 2.5$ & $1.5 \times 1.5$ & $15 \times 15$ & $10 \times 10$ & $10 \times 10$ \\
\hline & MS & $30 \times 30$ & $10 \times 10$ & $10 \times 10$ & $6.0 \times 6.0$ & $30 \times 30$ & $\begin{array}{l}10 \times 10 \\
20 \times 20 \\
60 \times 60\end{array}$ & $\begin{array}{l}10 \times 10 \\
20 \times 20 \\
60 \times 60\end{array}$ \\
\hline \multicolumn{2}{|c|}{$\begin{array}{c}\text { Radiometric } \\
\text { resolution [bit] }\end{array}$} & 8 & 8 & 8 & 12 & 12 & 12 & 12 \\
\hline \multicolumn{2}{|c|}{ Footprint [km] } & $185 \times 185$ & $60 \times 60$ & $70 \times 70$ & $60 \times 60$ & $185 \times 185$ & 290 & 290 \\
\hline \multicolumn{2}{|c|}{$\begin{array}{l}\text { Maximum angle } \\
\text { of incidence }\end{array}$} & $0^{\circ}$ & $+/-31^{\circ}$ & & $+/-27^{\circ}$ & $0^{\circ}$ & $+/-46^{\circ}$ & $+/-46^{\circ}$ \\
\hline
\end{tabular}

Source: own elaboration based on: Airbus Defence and Space 2018, Satellite Imaging Corporation 2018, ESA Earth Online 2018.

about the current status of land cover, while the extent of flood waters has frequently been obtained on the basis of radar data.

\section{Optical satellite systems}

Optical satellite remote sensing systems are characterized by a variety of technical parameters, including very important spatial and spectral resolution. Both of these parameters are crucial for monitoring the condition of embankments and forecasting the occurrence of floods. A detailed analysis of currently available VHRS and VHR satellite data was carried out, both in terms of their spatial resolution and their spectral resolution (Tables 1 and 2). The tables present the currently operating satellite systems as well as the systems operating in 2010 , because this was a year in which there was a flood threat in Poland and data from this period can be used as part of the research to test various image processing methods in terms of flood risk monitoring.

Table 1 presents all available VHRS optical satellites, along with their characteristics. Among these systems, WorldView-2 data was analysed, mainly due to the availability of data for the area of interest during the flooding and Plèiades data was analysed because of the daily revisit time and future use of data in the SAFEDAM system.

Table 2 presents selected HRS optical satellites, along with their characteristics, as a complement to the VHRS data. Sentinel-2 was chosen for research because of the free data policy and convenient access to the imagery database.

The temporal resolution of the satellite systems means the revisit time and the possibility of acquiring new imageries. For the area of medium latitudes, this ranges from 1-2 days (Plèiades and SPOT constellation) up to several days (e.g. LANDSAT, Sentinel). It depends on the construction of the satellite system (a single satellite or a constellation, a scanner operating only in a nadir or a scanner with the possibility of tilting along and across the direction of flight), and the possibilities of its programming. In the case of individual satellite systems with HVRS, where programming is possible, it is usually a few days (3-4 days). For preventive monitoring this is a sufficient revisit time, but the possibilities of the usage of satellite optical systems are limited by the weather conditions and cloud cover. The experience so far shows that it is generally possible to obtain optical data every 
Table 3. Damage identification based on VHRS $0.3 \mathrm{~m} \times 0.3 \mathrm{~m}$ pixel optical data

\begin{tabular}{|c|c|c|c|c|}
\hline Type of damage & Damage & $\begin{array}{c}\text { Dimensions } \\
\text { (approximate) }\end{array}$ & $\begin{array}{c}\text { Spectral } \\
\text { ranges }\end{array}$ & $\begin{array}{c}\text { Estimated accuracy of } \\
\text { results }\end{array}$ \\
\hline $\begin{array}{c}\text { Damage / loss of } \\
\text { ground }\end{array}$ & $\begin{array}{c}\text { Den, cavity, tunnel caused by the } \\
\text { activity of burrowing animals }\end{array}$ & $0.1-1 \mathrm{~m}$ & VIS, NIR & $0.3-0.6 \mathrm{~m}$ \\
\hline Surface damage & Traces in the crown of the levees & $0.1-0.3 \mathrm{~m}$ & VIS, NIR & $0.15-0.30 \mathrm{~m}$ \\
\hline
\end{tabular}

Source: Own elaboration

Table 4. Damage identification based on VHRS $0.5 \mathrm{~m} \times 0.5 \mathrm{~m}$ optical data

\begin{tabular}{|c|c|c|c|c|}
\hline Type of damage & Damage & $\begin{array}{c}\text { Dimensions } \\
\text { (approximate) }\end{array}$ & $\begin{array}{c}\text { Spectral } \\
\text { ranges }\end{array}$ & $\begin{array}{c}\text { Estimated accuracy of } \\
\text { results }\end{array}$ \\
\hline Surface damage & Wild crossings & $0.3-1 \mathrm{~m}$ & VIS, NIR & $0.3-0.5 \mathrm{~m}$ \\
\hline Surface damage & $\begin{array}{c}\text { Defects in the body and on the sides } \\
\text { of the levees caused by wild and } \\
\text { burrowing animals }\end{array}$ & Unspecified & VIS, NIR & $0.3-0.5 \mathrm{~m}$ \\
\hline Slope deformation & Local soil runoff & Unspecified & VIS, NIR & $0.3-0.5 \mathrm{~m}$ \\
\hline
\end{tabular}

Source: Own elaboration

7-10 days. However, there are periods when obtaining optical data is impossible due to unfavourable weather conditions.

Capabilities and restrictions of usage of earth observation

Optical data, due to frequent cloudiness occurring in the period of increased flood hazard, is less commonfor operational use in monitoring damage to levees. It is possible to use such data only in cloudless conditions or in the presence of slight cloud cover. This means that the identification of damage to flood embankments with the use of optical data can be carried out as quasi-continuous monitoring, conducted in order to detect damages early. Examples of optical data with very high spatial resolution (IKONOS, QuickBird) being used to identify damage to flood embankments are shown in the literature - these cover, for example, damage to the sod in the main body of the embankment and on the embankment slopes (Hossain et al. 2004). Optical data is much more frequently used to assess the state of damage after a flood event or to determine the extent of flooding, or for flood risk assessment (Stancalie et al. 2007; Ho et al. 2010; Skakun 2012; Shaker et al. 2012; Asare-Kyei et al. 2015; Byun et al. 2015; Hu et al. 2015; Malinowski et al. 2015).

In order to clarify the nomenclature and build a coherent vocabulary, the following definitions are provided: 'identification', as the possibility of indicating the location of the damage, but without specifying its type, and 'recognition', as providing the type of damage, which seems quite a limited task in the context of satellite images, especially those with high resolution. As a result of the analysis of the type and size of the potential damage to flood embankments and the available satellite data (Tables 1, 2), the possibilities of using individual types of optical data to identify damage to flood embankments have been indicated (Tables $3,4,5)$. Most often with this analysis, it is possible to point out a potential place of damage, but without indicating the cause. Satellite data is only used to monitor and indicate places for more accurate measurements. Supplementary measurements based on more precise technologies are recommended.

Levee monitoring and identification based on VHRS optical data

Using optical data with a maximum spatial resolution of $0.3 \mathrm{~m}$ $\times 0.3 \mathrm{~m}$ it is possible to detect damages of size equal to or bigger than $0.3 \mathrm{~m} \times 0.3 \mathrm{~m}$. Table 3 presents the estimated accuracy of results based on the use of airborne imagery or satellite data with the highest available resolution, such as WorldView-3. It is possible to see a smaller artefact on a VHRS image, but it is not feasible to determine details such as type of damage.

Table 4 presents the estimated accuracy of results based on the use of optical VHRS data with a $0.5 \mathrm{~m} \times 0.5 \mathrm{~m}$ pixel size. An example of satellite sensors are Plèiades satellites.

Figure 1 presents damaged flood banks caused by animals. The holes were caused by the beavers living in the area. Grazing animals on the levees and in their immediate vicinity violates the construction of levees and causes changes in soil mass.

\section{Damage identification based on HRS optical data}

Table 5 presents the estimated accuracy of results for optical data with a $2 \mathrm{~m} \times 2 \mathrm{~m}$ pixel size. It is possible to use SPOT 6 and 7 data to identify damage with approximate dimensions of 2-5 metres and higher. Large-scale damage, with dimensions of several or several dozen metres can be detected on the basis of optical data with a $10 \mathrm{~m} \times 10 \mathrm{~m}$ pixel, such as Sentinel-2.

Figure 2 presents an example of a landslide in Poland in 2015 and levee surface damage caused by people. Wheel rims are clearly visible, probably from cars, quads or agricultural machinery. The levee must maintain the correct geometry. Changes in the soil mass cause shifts in the geometry and changes in shaft stability. In the case of traces, water is collected in them and the filtration is disturbed, which reduces the stability of the shaft.

Analysis of the possibilities of using optical data in flood risk monitoring

Purpose of the research

The main goal of the research is to examine the potential and effectiveness of the optical satellite data in flood risk monitoring. As input data, Plèiades (10.06.2010) and WorldView-2 (20.06.2013) data was used. Sentinel-2 imageries had also been taken into account earlier, but they were excluded from the research due to low spatial resolution. As mentioned above, this data is more suitable for large area changes. The concept of SAR and optical Sentinel data use for flood risk monitoring in Poland, prepared as part of the SAFEDAM project, was presented by Pluto-Kossakowska et al. (2017).

\section{Research methodology}

The research methodology is based on bare soil and water body detection using optical satellite imagery. Therefore, 


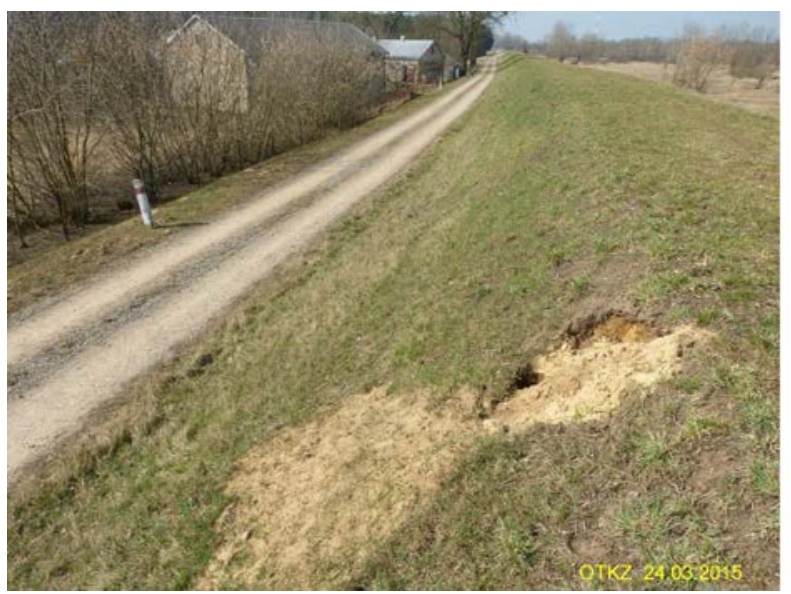

(a)

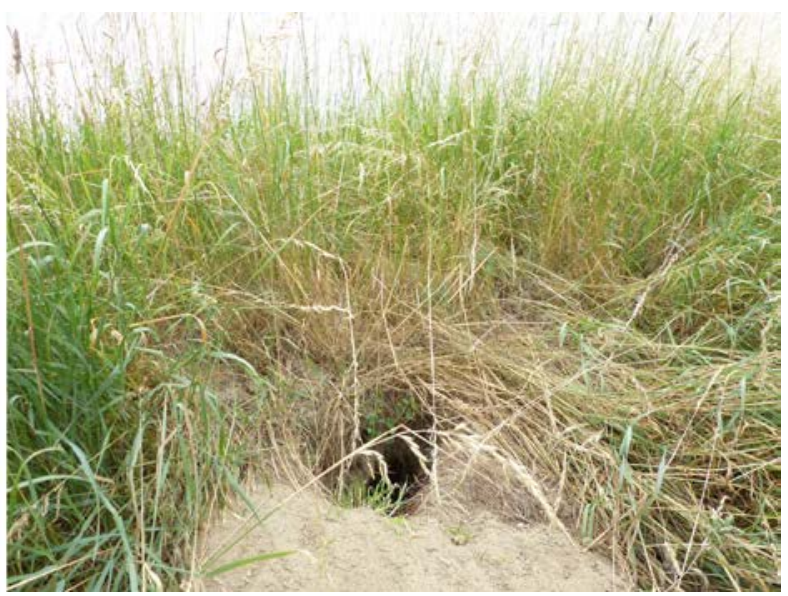

(b)

Figure 1. Presents damaged flood banks caused by animals. The holes were caused by the beavers living in the area. Grazing animals on the levees and in their immediate vicinity violates the construction of levees and causes changes in soil mass. Photo by Janusz Orzepowski

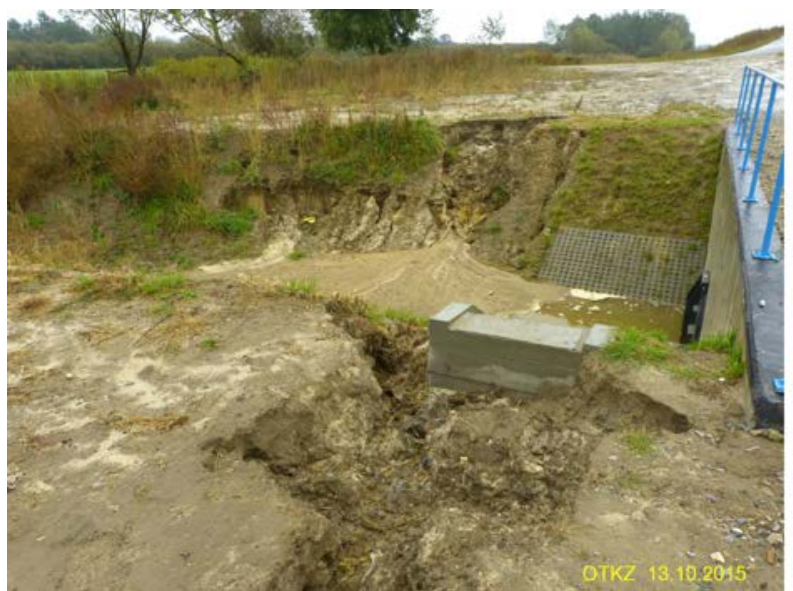

(a)

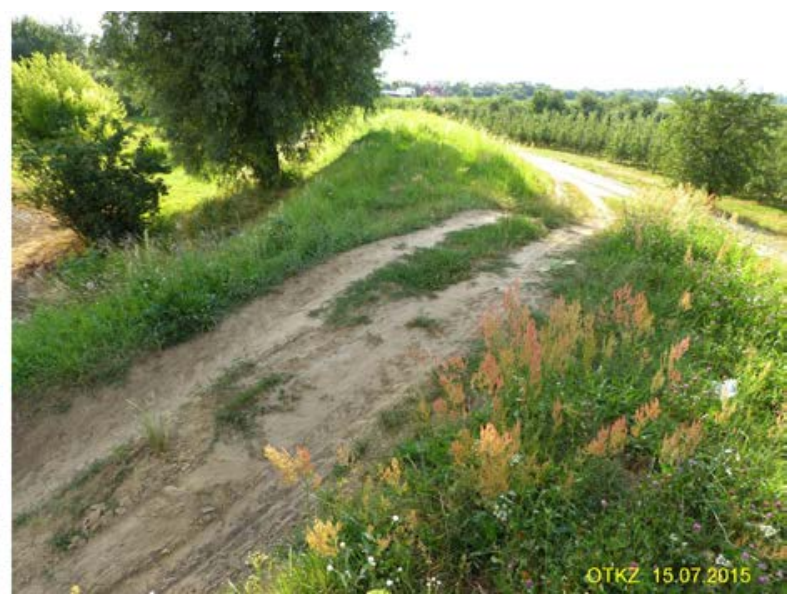

(b)

Figure 2. Presents an example of a landslide in Poland in 2015 and levee surface damage caused by people. Photo by Janusz Orzepowski

Table 5. Damage identification based on HRS $2 m \times 2 m$ optical data

\begin{tabular}{|c|c|c|c|c|}
\hline Type of damage & Damage & $\begin{array}{c}\text { Dimensions } \\
\text { (approximate) }\end{array}$ & $\begin{array}{c}\text { Spectral } \\
\text { ranges }\end{array}$ & $\begin{array}{c}\text { Estimated accuracy } \\
\text { of results }\end{array}$ \\
\hline Surface defects & Theft of part of the infrastructure & $2-10 \mathrm{~m}$ & VIS, NIR & $1-2 \mathrm{~m}$ \\
\hline Surface damage & Transhumance within the body of the levee & $2-10 \mathrm{~m}$ & VIS, NIR & $1-2 \mathrm{~m}$ \\
\hline Landslides & $\begin{array}{c}\text { Possibility of landslide in the section with } \\
\text { very low geotechnical parameters }\end{array}$ & $\begin{array}{c}\text { from several to } \\
\text { dozens of metres }\end{array}$ & VIS, NIR & $1-2 \mathrm{~m}$ \\
\hline Landslides & $\begin{array}{c}\text { Undercutting of the base of the levee by the } \\
\text { current of the river during floods }\end{array}$ & $\begin{array}{c}\text { from several to } \\
\text { dozens of metres }\end{array}$ & VIS, NIR & $1-2 \mathrm{~m}$ \\
\hline Cracks in the body & Longitudinal slits & $5-15 \mathrm{~m}$ & VIS, NIR & $1-2 \mathrm{~m}$ \\
\hline Blur of the shaft & $\begin{array}{c}\text { May occur when the flood wave elevation } \\
\text { is greater than the lowest point of the levee } \\
\text { crown }\end{array}$ & Unspecified & NIR & $1-2 \mathrm{~m}$ \\
\hline
\end{tabular}

Source: Own elaboration

vegetation and soil indices utilizing some of the image bands were used. Furthermore, the bare soil and water body areas can be converted to vector layers and compared with other data (Airborne Laser Scanning, reference water boundaries, range of water for warning state, range of water for emergency state, etc.), which is useful in the analysis of data acquired with different sensors and over different time periods, as is the case in the SAFEDAM project (Figure 3).

In the presented approach two analyses were conducted. The first analysis consisted of bare soil detection (places of potential levee damage), based on the Soil-adjusted Vegetation Index $(\mathrm{SAVI})$, the Optimized Soil-adjusted Vegetation Index (OSAVI), 


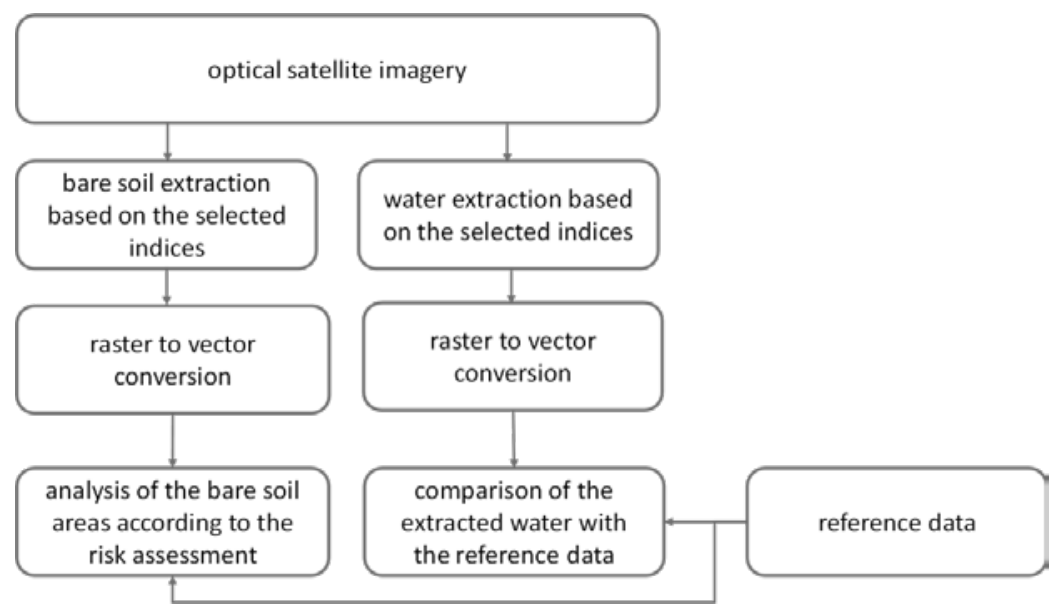

Figure 3. Workflow of optical satellite imagery analysis Source: Own elaboration

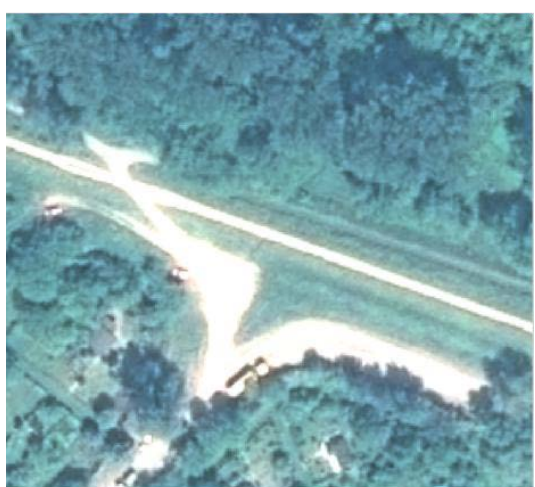

(a)

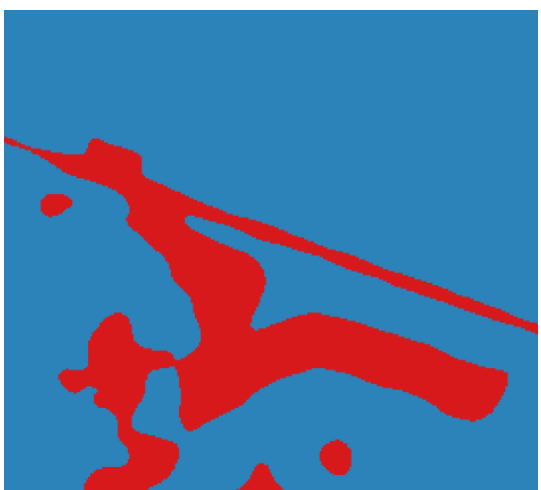

(b)

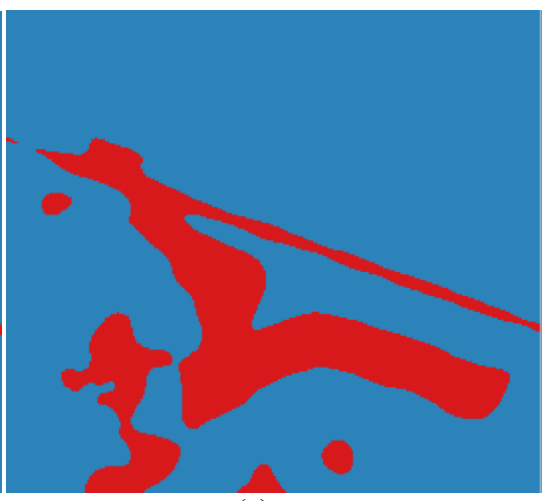

(c)

Figure 4. Bare soil detection based on Plèiades data (a) using MSAVI (b) and NDVI (c) Source: Own elaboration based on Pleiades data

the Optimized Soil-adjusted Vegetation Index using green band (OSAVI-G), and the Modified Soil-adjusted Vegetation Index (MSAVI).

The second analysis consisted of water range detection, based on the Normalized Differential Vegetation Index (NDVI), the Normalized Difference Water Index (NDWI), the Soil-adjusted Vegetation Index (SAVI), the Simple Ratio (SR), the Wetness (TCA) component, the Differential Vegetation Index (DVI), the Atmospherically Resistant Vegetation Index (ARVI), the Index of Free Water (IFW), the Water Index (WI), and the Water Impoundment Index (WII).

\section{Results and evaluation}

The aim of the conducted analysis was to identify indices to delimit the bare soil, as a signal that the structure of the shaft and the water range may have changed unambiguously during a flood, and to determine the threshold values at which the best and reproducible results are obtained. The analysis was conducted for optical satellite imagery which is used in the prevention of flood hazards. In the SAFEDAM project, the detection of bare soil and water is conducted automatically; therefore, it is important to use reliable indices.

Figure 4 illustrates an example of bare soil detection based on Plèiades data. The best results in bare soil detection were obtained using the MSAVI and NDVI indices. The MSAVI threshold was 0.065 , while the NDVI values for bare soil ranged from -0.1 (wet soil) to 0.1 (dry soil). As can be seen, some parts of the bare soil are overestimated, which may be caused by the shadows and low greenness level of the vegetation.

Figure 5 shows the results of water body detection. One of the problems which may occur during water body extraction involves elements which are beyond the river, which may be interpreted as water - for example, areas of shadow or building roofs. Therefore, it is necessary to filter the extracted water and include only the real water body in further flood risk analysis. The NDVI, OSAVI and SAVI indices proved to be the most stable when detecting water [Table 6]. Using these indices, it is possible to find a threshold value that will enable the automatic detection of water bodies. In some cases, NDWI and ARVI give very good results, but the threshold for all analysed data (Sentinel-2, WorldView-2 and Plèiades) could not be unambiguously determined. Regarding the WI index, it was determined that it significantly overestimates the water range by including shaded areas. As a result of the conducted research, it was found that the most effective at delimiting water was the NDVI index, for which a threshold value of -0.22 gives reproducible results (for cloudless images). Using a threshold value which is too high results in a larger error of commission (Table 6) - the built-up areas (roofs 


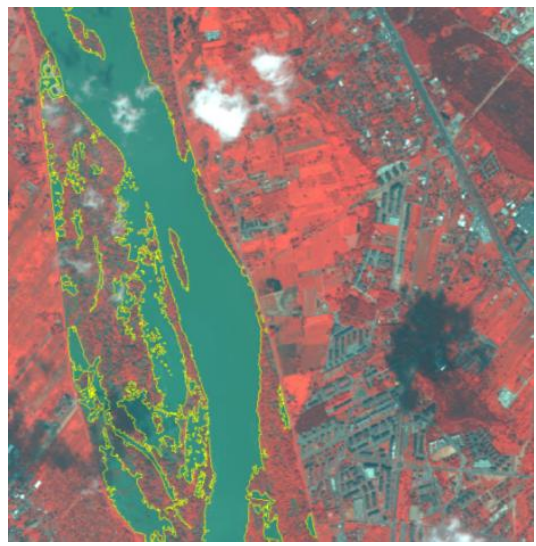

(a)

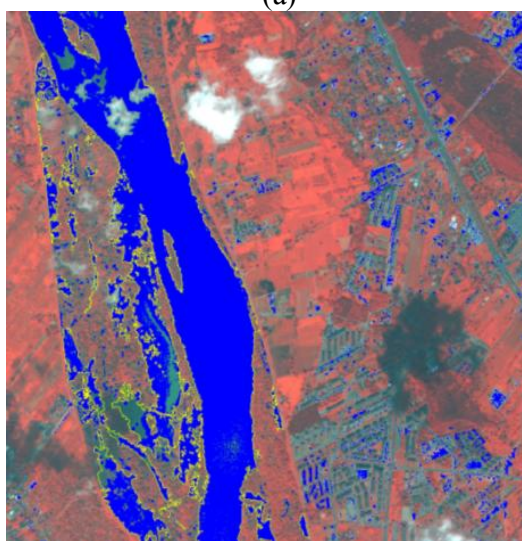

(d)

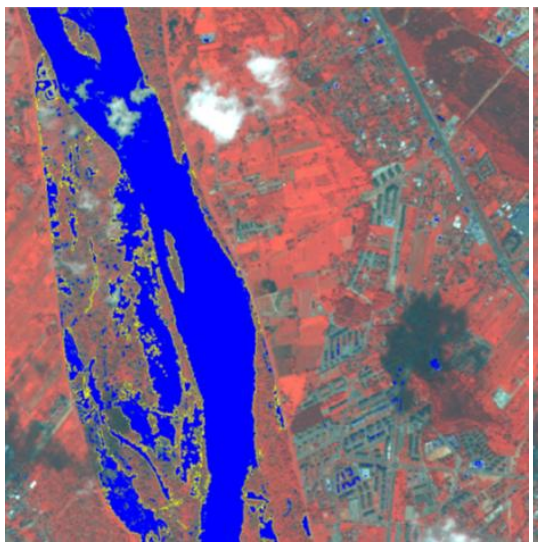

(b)

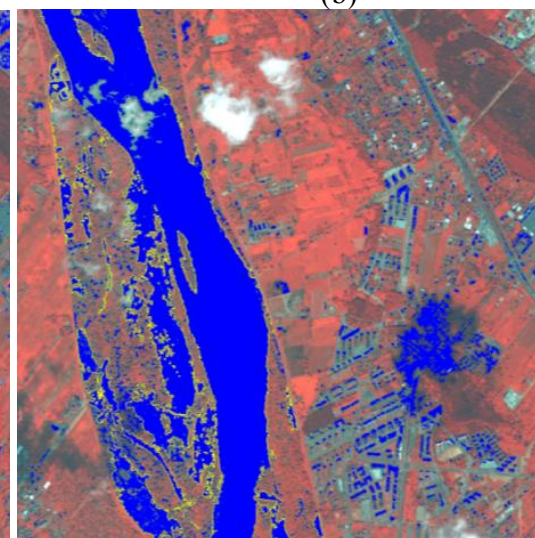

(e)

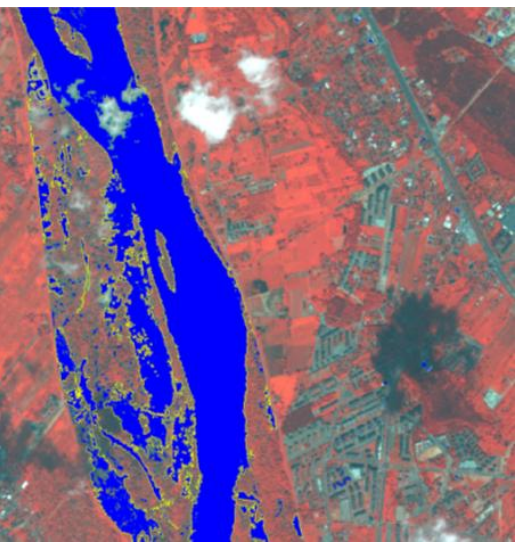

(c)

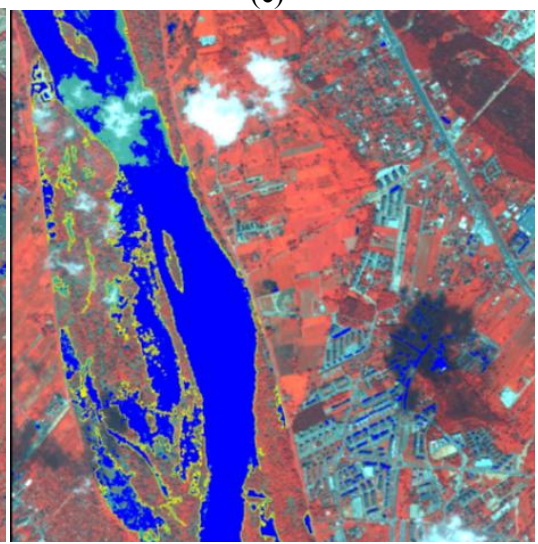

(f)

Figure 5. Detection of water bodies based on WorldView-2 (a) data using NDVI (b), SAVI (c), SARVI (d), WV-WI (e) and NDWI (f) results comparison with reference data (a)

Source: Own elaboration based on WorldView-2 data
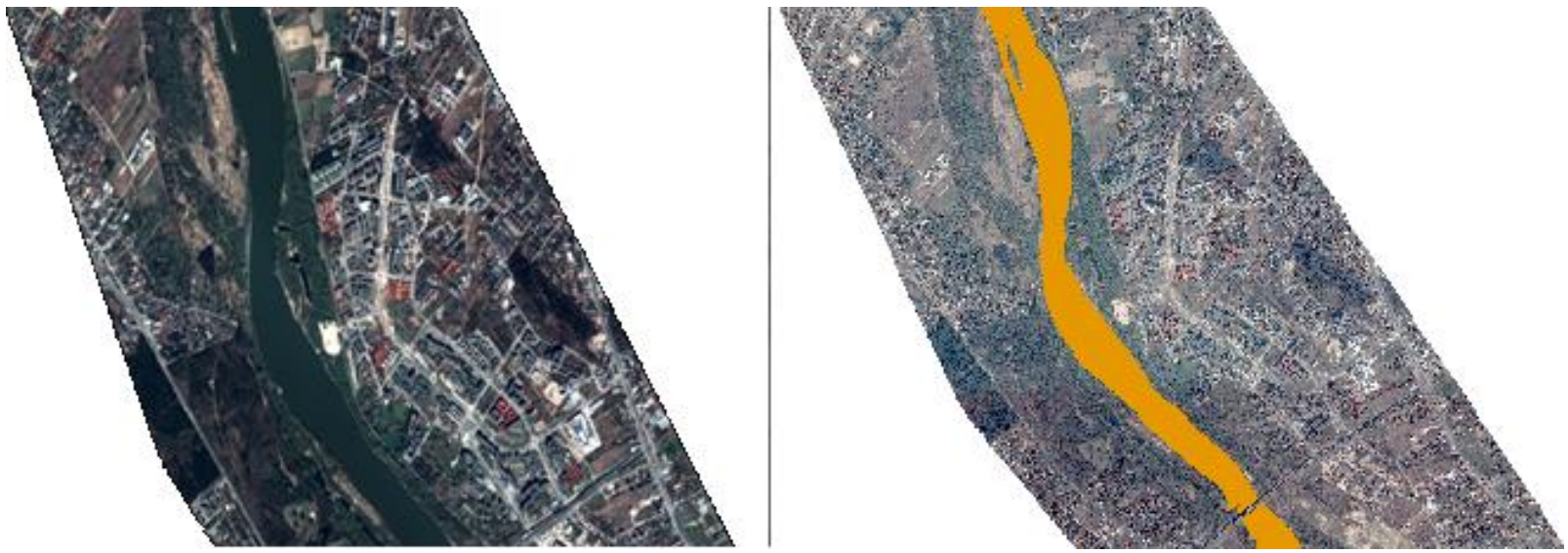

Figure 6. Detection of water bodies based on Plèiades data using NDVI Source: Own elaboration based on Pleiades dat

covered with roofing paper) can be incorrectly indicated as water areas. In the presence of clouds (Cirrus, Cirrostratus, Cirrocumulus or Altostratus) on the satellite image, a two-stage operation is necessary: 1 . cloud detection (for Sentinel-2 data, the cloud masks provided by ESA can be used), 2. water detection with a NDVI threshold value between -0.13 and -0.10 .

Figure 6 presents the results of Plèiades data processing. The extracted water body area covers the water presented on the satellite scene properly.
The analysis shows that it is clearly possible to detect damage in turf on levees of not less than $0.3 \mathrm{~m}$. Minor changes of a few or a few dozen centimetres are impossible to recognise. Only significant changes can be detected using satellite imagery with a resolution of $5 \mathrm{~m} \times 5 \mathrm{~m}$ or more. Examples of such damage may be those related to human activity, with approximate dimensions of 10-15 metres. Sentinel-2 can be used to identify large area changes. The automatization of satellite data processing (from different satellite systems) gives opportunities for hydrological 
Table 6. Assessment of the accuracy of determining the range of water bodies on the basis of index images obtained from WorldView-2 data (partly cloudy)

\begin{tabular}{|c|c|c|c|c|}
\hline Index & Threshold values & Correctly detected water & Error of omission & Error of commission \\
\hline DVI & $<-30$ & $71.61 \%$ & $28.39 \%$ & $2.93 \%$ \\
\hline NDVI & $<-0.14$ & $94.76 \%$ & $5.24 \%$ & $10.04 \%$ \\
\hline NDVI & $<-0.15$ & $94.40 \%$ & $5.60 \%$ & $7.54 \%$ \\
\hline NDVI & $<-0.16$ & $\mathbf{6 3 . 9 9} \%$ & $10.27 \%$ & $\mathbf{5 . 6 8 \%}$ \\
\hline NDVI & $<-0.22$ & $89.73 \%$ & $21.43 \%$ & $1.40 \%$ \\
\hline NDWI & $>0.32$ & $78.57 \%$ & $5.04 \%$ & $6.24 \%$ \\
\hline SAVI & $<-0.20$ & $94.96 \%$ & $\mathbf{6 . 4 3} \%$ & $12.01 \%$ \\
\hline SAVI & $<-0.25$ & $93.66 \%$ & $\mathbf{7 . 0 3} \%$ & $\mathbf{4 . 7 1 \%}$ \\
\hline SAVI & $<-0.27$ & $92.97 \%$ & $11.52 \%$ & $3.49 \%$ \\
\hline OSAVI & $<-0.25$ & $90.22 \%$ & $4.37 \%$ & $1.56 \%$ \\
\hline SARVI & $<-0.4,0.0>$ & $88.48 \%$ & $6.64 \%$ & $15.01 \%$ \\
\hline ARVI & $<-0.1$ & $85.06 \%$ & $8.74 \%$ & $14.94 \%$ \\
\hline WV-WI & -0.5 & $93.36 \%$ & $19.88 \%$ \\
\hline WV-WII & $<29$ & $91.26 \%$ & $16.49 \%$ \\
\hline
\end{tabular}

Source: Own elaboration

services and crisis management professionals to access the accurate and actual information about the condition of levees for the early detection of flood risk.

The initial results of the studies (using vegetation, soil and water indices based on satellite data) demonstrate the potential of very high and high-resolution satellite imagery for the operational detection of damage and risk areas:

- $\quad$ minor changes of a few and a few dozen $\mathrm{cm}$ are virtually impossible to recognise. There must be special conditions (e.g. high contrast with the surrounding terrain) so that they can be seen in satellite imagery;

- changes below $1 \mathrm{~m}$ can be detected using VHR images such as WorldView-3, WorldView-2, GeoEye, Plèiades;

- changes from 1 to several metres can be detected using SPOT 6 and 7 images;

- only significant changes with approximate dimensions of 10-15 metres can be detected using satellite imagery with a resolution of $5 \mathrm{~m} \times 5 \mathrm{~m}$ or more, such as Sentinel- 2 data.

Discussions and conclusions

The main goal of the SAFEDAM project is to create an IT system for managing spatial data related to levees. The system will enable data collection with a non-invasive method of data acquisition (UAV and satellite data), automatic data analysis, visualization for hydrological services and for society, and provide tools for crisis management professionals and rescue teams during the intervention phase.

Earth observations are one of the key elements of the system, providing continuous information about a large area of interest at the same time. Analysis based on satellite data is used in both preventive and intervention mode. Satellite data can be used for large-scale image analysis to pre-select areas dedicated to unmanned platform measurement. Using processing and the observation of time series, the multi-temporal analysis tool may indicate simple analyses based on vegetation indices, to identify landslide areas, the occurrence of illegal objects, anthropopressure and the impact of animals.
As a result of the conducted analysis it was found that NDVI is the most suitable index for the automatic determination of a water range with a threshold value of -0.22 (for cloudless satellite scenes). This threshold value makes it possible to detect water with a slight overestimation error of $1-1.5 \%$ of the reference water mask area. In Rokni et al. (2014), where Landsat imagery was used for water surface detection, similar NDVI values were acquired $(-0.21$ and -0.29$)$. However, the detection accuracy in Rokni et al. (2014) was slightly higher, which may have been caused by the selection of a more homogeneous, water-covered area than the test area selected for this study (Fig. 5). Moreover, whereas the NDWI and modification of this index gives accurate results in many studies (El Asmar et al. 2013; Rokni et al. 2014), in the analysis presented above the NDWI-based water detection was not satisfactory. Additionally, according to the proposed approach, in the event that high-level clouds (e.g. Cirrus) or middle-level clouds (e.g. Altus) occur over the analysed area, it is necessary to apply a two-stage processing workflow and two different threshold values for cloudless and cloudy parts of the scene.

Damage and changes on the surface of the embankments are detectable, but it is difficult to clearly determine the type and cause. The presented research has shown that damage visible as bare soil can be detected using the MSAVI or NDVI indices. However, if the threshold value is too high, the bare soil is overestimated.

This feasibility study will support the SAFEDAM System by providing a clear overview of the existing optical satellite systems and their capabilities, as well as taking into account their limitations.

\section{Acknowledgements}

The research was conducted as part of the SAFEDAM project - "Advanced technologies in the prevention of flood hazard", financed by the National Centre for Research and Development. 


\section{References}

Airbus Defence and Space, 2018. Available from: <www. intelligence-airbusds.com>. Access: 12/10/2017.

Asare-Kyei, D, Forkuor, G \& Venus, V 2015, 'Modeling Flood Hazard Zones at the Sub-District Level with the Rational Model Integrated with GIS and Remote Sensing Approaches', Water, vol. 7, pp. 3531-3564.

Byun, Y, Han, Y \& Chae, TB 2015, 'Image Fusion-Based Change Detection for Flood Extent Extraction Using Bi-Temporal Very High-Resolution Satellite Images', Remote Sensing, vol. 7, pp. 10347-10363. DOI:10.3390/rs70810347.

Cundill, SL, van der Meijde, M, Robert, H \& Hack, GK, 2014, 'Investigation of Remote Sensing for Potential Use in Dike Inspection', IEEE Journal of Selected Topics in Applied Earth Observations and Remote Sensing, vol. 7, pp. 733-746.

DigitalGlobe 2018. Available from: <www.digitalglobe.com>. Access: 12/10/2017.

El-Asmar, HM, Hereher, ME \& El Kafrawy, SB 2013, 'Surface area change detection of the Burullus Lagoon, North of the Nile Delta, Egypt, using water indices: A remote sensing approach', The Egyptian Journal of Remote Sensing and Space Science, vol. 16(1), pp. 119-123.

ESA Earth Online 2018. Available from: <https://earth.esa.int> Access: 25/03/2018.

Ho, LTK, Umitsu, M \& Yamaguchi, Y 2010, 'Flood Hazard Mapping By Satellite Images And Srtm Dem In The Vu Gia Thu Bon Alluvial Plain, Central Vietnam', Int. Archives of the Photogrammetry, Remote Sensing and Spatial Information Science, vol. XXXVIII, part 8, Kyoto Japan.

Hossain, A \& Easson, G 2004, Application of High Resolution Multispectral Imagery for Levee Slide Detection and Monitoring, Department of Geology and Geological Engineering, The University of Mississippi.

Hu, Y, Huang, J, Du, Y, Han, P \& Huang, W 2015, 'Monitoring Spatial and Temporal Dynamics of Flood Regimes and Their Relation to Wetland Landscape Patterns in Dongting Lake from MODIS Time-Series Imagery', Remote Sensing, vol. 7 , pp. 7494-7520. DOI:10.3390/rs70607494.
Malinowski, R, Groom, G, Schwanghart, W \& Heckrath, G 2015 'Detection and Delineation of Localized Flooding from WorldView-2 Multispectral Data', Remote Sensing, vol. 7, pp. 14853-14875. DOI:10.3390/rs71114853.

Opole-nasze miasto, 2015. Available from: <http://opole. naszemiasto.pl>. Access: 20/12/2017.

Pluto-Kossakowska, J, Osińska-Skotak, K, Łoś, H \& Weintrit, B 2017, 'The Concept of SAR Satellite Data Use for Flood Risk Monitoring in Poland', Signal Processing Symposium 2017, Jachranka, Poland, pp. 1-5. DOI: 10.1109/ SPS.2017.8053662.

Rokni, K, Ahmad, A, Selamat, A \& Hazini, S 2014, 'Water feature extraction and change detection using multitemporal Landsat imagery' Remote Sensing, vol. 6(5), pp. 4173-4189.

Satellite Imaging Corporation 2018, Available from: <www. satimagingcorp.com>.

Sądeczanin, 2014. Available from: <http://archiwum.sadeczanin. info>. Access: 21/12/2017.

Skakun, S 2012, 'The Use Of Time-Series Of Satellite Data To Flood Risk Mapping', International Journal Information Models and Analyses vol.1, pp. 260-270..

Shaker, A, Yan, WY \& El-Ashmawy, N 2012, 'Panchromatic Satellite Image Classification for Flood Hazard Assessment', Journal of Applied Research and Technology, vol. 10, pp. 902-910.Stancalie, G, Craciunescu, V \& Irimescu, A 2007, 'Contribution of Earth observation data supplied by the new satellite sensors in flood risk mapping', Remote Sensing for Environmental Monitoring and Change Detection, Proceedings of Symposium HS3007 at IUGG2007, Perugia, July 2007, IAHS Publ. vol. 316. 